\title{
The Effectiveness of Online Citizenship Education Learning on Student Motivation During the Coronavirus Pandemic (Covid-19)
}

\author{
Enandia Pandikar ${ }^{1, *}$ Edy Sofyan $^{2}$ \\ 1,2 STKIP Pasundan, Cimahi, Indonesia \\ ${ }^{*}$ Corresponding author. Email: epandikar@stkippasundan.ac.id
}

\begin{abstract}
This research was motivated by the conditions of student learning during the Covid-19 pandemic, which affected the effectiveness of Civics education with online learning on student learning motivation of class X at SMAN 2 Padalarang. The formulation of the problem in this study; 1) How is the effectiveness of Civics education with online learning at SMAN 2 Padalarang; 2) How high was the student's learning motivation at SMAN 2 Padalarang during the Covid-19 pandemic; 3) How much influence is the effectiveness of Civics education with online learning on student learning motivation during the Covid-19 pandemic at SMAN 2 Padalarang. This study uses a correlation method with a quantitative approach as well as a propotionate stratified random sampling technique with the results of the study showing that: 1) There is an effect of the effectiveness of Civics education withonline learning based on the results of $t$ count 6.397> $\mathrm{t}$ table 1.671.2) There is an overall effect of the comparison, it can be concluded that $\mathrm{H} 0$ is rejected and $\mathrm{H} 1$ is accepted from the results of $\mathrm{f}$ count $40.919>\mathrm{f}$ table 3.11 with a significant level obtained from the results of the F ANOVA test is $0.000<0.005$. 3) The result of the correlation value of PPM variable $\mathrm{X}$ is 0.584 which is interpreted as "medium". 4) The influence of the independent variable on the dependent variable is $33.3 \%$, while the other $66.7 \%$ is influenced by factors outside the study, which means that the determination between the variables is said to be moderate.
\end{abstract}

Keywords: Effectiveness, Civics Education, Student Learning Motivation.

\section{INTRODUCTION}

In 2019 the world was shocked by the outbreak of a disease caused by a virus, namely Covid-19 (Corona Virus Disease) or what is known as the corona which has spread to 222 countries including Indonesia. Quoting data from Worldometes, Monday (28/09/2020) at 15.30 WIB, there were $33,327,897$ confirmed cases worldwide, of which 24,646,808 patients had recovered and $1,002,665$ patients died. That way the active cases of the corona virus in the world were recorded as many as $7,678,424$, including Indonesia. In Indonesia alone, 278,722 confirmed cases were recorded, of which 206,870 patients had recovered and 10,473 patients died. That way, the total active cases in Indonesia were recorded at 61,379 .

In West Java, PSBW (Regional-Scale Social Restrictions) are being implemented which causes many negative impacts on society such as health, economy, social and education. Especially the impact on education causes indecision in carrying out teaching and learning activities, therefore it requires learning methods that are suitable for the current situation and efforts to break the chain of spreading Covid-19 in order to re-implement effective learning.

For months the Covid-19 pandemic has hit the realm of education until the new school year takes place. The level of the spread of Covid-19 continues to increase as a way to anticipate it, educational units are not allowed to carry out face-to-face learning, even with the implementation of a very strict Covid-19 pandemic prevention protocol. The way educational units carry out face-to-face learning is a method that should be avoided in the learning policy agenda. Therefore, like it or not, whether we like it or not, all educational units are encouraged to be able to carry out PJJ (Distance Learning) online or offline.

This change is based on the issuance of the Minister of Education and Culture Circular Letter Number 3 of 2020 concerning the Prevention of Corona Virus Disease (Covid-19) in the Education Unit, the Circular of the Minister of Education and Culture Number 4 of 2020 concerning Implementation of 
Education Policies in the Emergency of the Spread of Corona Virus Disease (Covid-19), Joint Decree of 4 (four) Ministers regarding Guidelines for Implementation of Learning in the 2020/2021 Academic Year and 2020/2021 Academic Year in the Pandemic Corona Virus Disease (Covid-19), as well as Circular of the Secretary General of the Ministry of Education and Culture Number 15 of 2020 concerning Guidelines for Organizing Learning from Home in the Emergency Period of Corona Virus Disease (Covid-19).

In E-learning or online learning, students can interact directly with the learning content they find in various formats such as video, audio, documents, and so on. Apart from that, they can also choose to order their own learning, be directed, and evaluate with the help of a teacher. These interactions can occur within the community using a variety of synchronous and asynchronous internet-based activities (video, audio, computer conferencing, chat, or virtual world interactions). Online learning media uses several portals and applications that are often used in general, namely Google Classroom, Zoom, WhatsApp, Google Meet, Google Form, and so on.

Even so, not all students and teachers can carry out learning with online methods. This happens because of the limitations that students and teachers have. Not all students have digital devices as required in online learning methods and not all teachers can carry out learning using the online method even though they have digital devices because of limitations in material aspects such as money to buy data packages, and the ability to use gadgets.

This situation certainly has an impact on the quality of learning, students and teachers who previously interacted directly now have to interact in a limited virtual space. Teachers are required to provide good teaching, especially in Civics lessons because as we know most students are less motivated in learning Civics, this is because teachers still use the lecture method so that the material taught becomes verbal / memorizing.

In addition, student learning motivation also influences learning success. This is consistent with what [1] stated that the learning process will achieve success if students have good learning motivation. Therefore, learning motivation is very important for every student, both intrinsic and extrinsic.

Online learning also affects student learning motivation, in online learning the teacher must be able to create a conducive and active class atmosphere to maintain student learning motivation so that learning can be achieved because the classroom climate has a significant influence on learning motivation. However, the conditions of online learning make it difficult for teachers to control and maintain the learning climate because they are limited in virtual space. This condition causes student learning motivation to decrease and even affect student learning outcomes.
Based on the above opinion, the author is very aware that the effectiveness of online Civics learning can affect student learning motivation. Therefore, the researcher is interested in examining the effect of the effectiveness of online Civics learning on student learning motivation to assess the effectiveness of the learning method.

Therefore, based on the description above, the researcher is interested in raising the title "The Effectiveness of Online Civics Learning on Student Motivation during the Covid-19 Pandemic at SMAN 2 Padalarang".

\section{THEORETICAL REVIEW}

Effectiveness is a condition that shows the extent to which the plan can be achieved. The more plans that can be achieved, the more effective the activity will be, so that the word effectiveness can also be interpreted as the level of success that can be achieved from a certain method or effort in accordance with the objectives to be achieved.

It can be concluded that a learning media can be said to be effective when it meets the criteria, including being able to influence, change or bring results. When we formulate instructional goals, effectiveness can be seen from how far these goals are achieved. The more goals are achieved, the more effective the learning media will be.

According to [2], the effectiveness of the learning process should be viewed from the relationship between certain teachers who teach certain groups of students, in certain situations in an effort to achieve certain instructional goals. The effectiveness of the learning process means the level of success of the teacher in teaching certain groups of students by using certain methods to achieve certain instructional goals.

According to [3] argues that the effectiveness of learning has two characteristics. The first characteristic is "making it easier for students to learn" something useful, such as facts, skills, values, concepts or something desired learning outcomes. Second, that skills are recognized by those who are competent to assess, such as teachers, supervisors, tutors or students themselves.

As for the understanding of the effectiveness of learning that is completely put forward by Miarso in the journal Rohmawati (2016) which states that the effectiveness of learning is one of the standards for the quality of education and is often measured by the achievement of goals, or it can also be interpreted as the accuracy in managing a situation "doing the right things".

The advancement of information and communication technology today provides many conveniences and possibilities in designing and developing an education system, especially online learning concepts and models or many who call it ELearning. 
One of the government instructions regarding activities carried out at home is learning activities. Learning must not stop. Teaching and learning activities (KBM) are moved at home, but must be controlled by teachers or lecturers and parents, using distance learning. This PJJ was initially carried out for approximately 14 days, but it did not rule out that it had been added again because of the situation and conditions of the development of Covid-19.

PJJ is needed nowadays by all students from elementary school to university level, and this is not only the case in Indonesia, but almost all over the world implementing E-learning. In e-learning or online learning, students can interact directly with learning content that they find in various formats such as video, audio, documents, and so on. Apart from that, they can also choose to order their own learning, be directed, and evaluate with the help of a teacher. These interactions can take place within the inquiry community, using a variety of synchronous and asynchronous internet-based activities (video, audio, computer conferencing, chat, or virtual world interactions).

In order to prevent the spread and transmission of Covid-19 within the educational unit, the Ministry of Education and Culture has taken a policy to close schools during the Covid-19 pandemic. During the closing period, teaching and learning activities were transferred through the implementation of BDR in the form of PJJ. This policy is in accordance with the Circular of the Secretary General of the Ministry of Education and Culture Number 15 of 2020 concerning Guidelines for Organizing Learning from Home in an Emergency for the Spread of Corona Virus Disease (Covid-19).

Citizenship Education is an effort to equip students with basic knowledge and abilities with regard to the relationship between citizens and the state as well as preliminary education to defend the state to become citizens so that the nation and state can rely [4]. Education that discusses the role of citizens in civic education includes basic understanding of governance, democratic procedures, care, attitudes, political knowledge so that they are able to make rational political decisions. This is intended to prepare democratic and participatory citizens through civic education that is oriented towards developing critical thinking and acting democratically [5].

The goal in citizenship education (PKn) is to be able to grow knowledge or insight as well as awareness in the state, attitudes and behaviors that love the homeland and unite the nation's culture, archipelago vision, as well as national resilience in each of the nation's successor candidates. who is also the one who studies and also the one who will master the imu of knowledge as well as technology and also art.

According to [6] states that: The goals and objectives of Citizenship Education are to be able to increase knowledge and also develop the ability to understand, live and also believe in the values of
Pancasila, which is as a guide in behaving in the life of society, nation and state so that it will become citizens. a country that is full of responsibility and is also reliable and can provide provisions for the ability to be able to learn further, learn so as to achieve predetermined Civics goals.

Motivation is an impulse that makes people act or behave in motivational ways that refer to the causes of behavior, such as the factors that encourage someone to do or not do something. While motivation, according to Mc Donald in [7] is a change in energy that occurs in an individual which is marked by the emergence of feelings and reactions or actions to achieve certain goals. And learning according to [8] is an effort process to get changes in behavior. It can be concluded that learning motivation is the overall driving force that lies within the student that raises the intention to carry out learning activities, so that the goals desired by the learning subject can be achieved. Whereas learning is the basic process of the development of human life, by learning humans make individual qualitative changes so that their behavior develops. All activities and achievements in human life are nothing but the result of learning, because someone lives and works according to what has been learned. Learning is not just an experience, learning is a process, not a result. Therefore, learning takes place actively and integratively by using various forms of action to achieve results. [9] says that learning is a mental / psychic activity that takes place in active interaction with the environment, which results in changes, knowledge, understanding, skills and attitudes, and those changes are relatively constant and constant. Meanwhile, what is meant by learning motivation is the desire that activates, moves, channels and directs individual attitudes and behavior to learn.

It can be concluded that the effectiveness of online Civics learning can affect student learning motivation because the effectiveness of teaching activities is limited by the existence of government regulations to maintain the health of students and teachers amid the Covid-19 pandemic by means of PJJ which often causes negative impacts in the form of difficulties in learning methods, learning media, as well as the facilities used in the learning process. In addition, in Civics learning, it is not uncommon for students to feel bored or bored because of the material in Civics learning. Therefore, it takes teacher activeness in increasing student motivation in online Civics learning to increase the effectiveness of learning in order to get maximum results.

\section{METHODS}

The scientific method according to Komara (Endang Komara's Blog: The Role of Philosophy of Science in Development) The scientific method is a procedure or systematic steps in obtaining scientific knowledge or science. Science is knowledge obtained through the scientific method. A method is a procedure or a way to find out something with systematic steps. In 
this study, researchers used a correlation method using a quantitative approach.

According to [10] the quantitative research method is called a positivistic method because it is based on the philosophy of positivism. This method is a scientific method because it fulfills scientific principles, namely concrete / empirical, objective, measurable, rational, and systematic. This method is also called the confirmative method, because this method is suitable for verification / confirmation. This method is called a quantitative method because the research data is in the form of numbers and the analysis uses statistics. Thus the quantitative method can be interpreted as a research method based on the philosophy of positivism, used to research on certain populations or samples, data collection using research instruments, data analysis is quantitative / statistical, with the aim of testing predetermined hypotheses.

This research is intended to prove the existence of a causal relationship between variables. According to Sugiyono [11], causal associative research is research that aims to determine the relationship between two or more variables. With this research it will be possible to build a theory that functions to explain, predict and control a symptom. A causal relationship is a relationship that is causal in nature, one variable (independent) affects another variable (dependent). The variables to be studied were the effectiveness of online Civics learning and student learning motivation.

In the research that is carried out, the researcher certainly compiles and prepares what will be studied, according to the research design. According to [12], a quantitative research design is built from several constructs such as: research title, problem background, problem formulation, research objectives, research benefits, literature review, hypotheses, conceptual research concepts, determination of variables and variable indicators, measurement, data sources, data collection methods, analysis design and data analysis methods.

\section{RESULT AND DISCUSSION}

At SMAN 2 Padalarang the learning process is carried out from home online or online is not as easy as imagined, so many things are thought and considered in order to achieve the learning objectives that we previously planned, including learning strategies, methods, models, even the availability of facilities that support online learning. the.

The conditions that occurred at SMAN 2 Padalarang in the 2020/2021 academic year during the Covid-19 pandemic, students were expected to be able to participate in online or online learning properly and there must be a capacity to support the participation of children, parents, cellphone equipment, pulses, textbooks, but not all students can take part in learning due to signal problems and applications from cellphones so that learning is not optimal.
The enthusiasm for learning can be owned by increasing the motivation to learn. Motivation to learn is a driving force and impetus that makes someone interested in learning so that they will learn continuously. Low motivation can lead to low success in learning so that it can lower student achievement. The learning process given to students in order to understand what has been said must make students happy or motivated in learning. This process will make an impression and provide thinking skills and form good character for students. Students will be more creative, intelligent and think optimally, able to solve problems together, and also respect other people around them. This learning has been promoted in the Teaching and Learning Process (PBM) at this time.

Students and students are invited to discuss, solve a problem, and then appear to present their work. And this has trained students to dare to express opinions and be responsible for what they get. Learning that is fun will be able to make students understand and motivated in learning. However, all learning must change, since March 16, 2020, students start learning online or online. The Covid-19 pandemic has forced students to take PBM online or online.

The first week of students followed excitedly. And also the assignment given by the teacher via WhatsApp (WA) was done well. The days go on and after almost two months students have to take part in online or online learning, but their enthusiasm has decreased because they feel boredom in learning. Their enthusiasm is not like the first week anymore, the assignments are collecting it too late, there are even students who do not submit assignments. There are many obstacles in the field, and many students also complain that they do not have an internet quota to participate in learning properly. And also the many tasks that pile up, the feeling of being bored with studying is very big. All teachers have given assignments and asked students to take photos of their assignments. Fun learning has finally become very boring learning for students. Students are not only as subjects but become objects of learning, therefore it is necessary to take steps to motivate students to learn again.

To test whether the sample used has a normal distribution or not, the Normality Test is used using the SPSS version 22 program with a linear regression model. A regression model that can be considered good is when the regression model is normally distributed or close to normal, so that it can be tested statistically. The data that has been processed by the researcher using SPSS version 22 states that the plot follows a diagonal line, so it can be concluded that the data is normally distributed so that the test can be continued to the next stage. The results of the normality test using the Kolmogrov Smirnov Test method show the results of $0.088>0.05$, which means that the results of the normality test above have a normal distribution. 
The $\mathrm{t}$ test is a temporary answer to the formulation of the problem, which asks for the relationship between two or more variables. Based on the data in statistical hypothesis decision taking, if the value of $t$ count $>t$ table. Then $\mathrm{H} \_0$ and $\mathrm{H} \_1$ are accepted, and vice versa if $\mathrm{t}$ count $<\mathrm{t}$ table. Then $\mathrm{H}_{-} \mathrm{-} 0$ is accepted and $\mathrm{H}_{-} 1$ is rejected. From the results of the $\mathrm{T}$ test the value of $\mathrm{t}$ count $=6.397$ and $\mathrm{t}$ table of $\mathrm{df}=(\mathrm{nk})=(81-2)=79$ using a $=0.05$ is 1.671 so that $\mathrm{t}$ count $=6.397>\mathrm{t}$ table $=1.671$ from the comparison can It was concluded that $\left[\mathrm{H} \rrbracket \_0\right.$ rejected and $\mathrm{H}_{-} 1$ was accepted, namely the Effectiveness of Online Civics Learning has an effect on Student Learning Motivation.

Hypothesis Testing Hypothesis testing as a whole regarding the independent variable on the dependent variable, the Fisher test ( $\mathrm{F}$ test) is used with a confidence level of $95 \%$ or $\alpha 0.05$. Anova $F$ test results obtained that the value of $\mathrm{F}$ count $=40.919$ while $\mathrm{F}$ table $(\mathrm{n} 1)=(\mathrm{K}-1)$ $=(2-1)=1 \mathrm{DF}(\mathrm{n} 2)=(\mathrm{nk})=(81-2)=79: \mathrm{a}=0,05$ is 3.11 so that $\mathrm{f}$ count $=40.919>\mathrm{ftabel}=3.11$. From this comparison, it can be concluded that $\left[\mathrm{H} \rrbracket{ }_{-} 0\right.$ is rejected and H_1 is accepted, which means that there is a significant overall effect between the independent variable and the dependent variable. The significant level obtained from the ANOVA F-test results is $0.000<0.005$. So it can be concluded that $\llbracket \mathrm{H} \rrbracket{ }_{-} 0$ is rejected and $\mathrm{H}_{-} 1$ is accepted, which means that there is a significant overall effect between the independent and dependent variables.

Pearson Product Moment (PPM) Test Is a test intended to test the coefficient of data based on the Pearson Product Moment Test (PPM) formula. The variable PPM correlation value is obtained, that the PPM value is 0.584 . So it can be concluded that the relationship or correlation is "moderate" because it is in the interval $0.40-0.599$.

The cause of the change in the dependent variable which comes from the independent variable is the square of the correlation coefficient. The coefficient of determination explains the magnitude of the influence of the value of a variable on the fluctuation (variation) of the variable value. The magnitude of the correlation value $(\mathrm{X})$ is 0.584 from the output, the coefficient of determination ( $\mathrm{R}$ Squere) is 0.333 . The effect of the independent variable (Online Civics Learning Effectiveness) on the dependent variable (Student Learning Motivation) was $33.3 \%$, while $66.7 \%$ was influenced by other factors or variables outside of this study. And it can be made a determination decision between the variables is said to be moderate.

Tabel 1: The Effectiveness of Online Civics Learning Against Student Motivation

\begin{tabular}{|c|l|l|}
\hline \multicolumn{2}{|c|}{ teacher } & \multicolumn{1}{c|}{ students } \\
\hline 1 & $\begin{array}{l}\text { Teachers can instruct } \\
\text { students well }\end{array}$ & $\begin{array}{l}\text { Students can follow } \\
\text { the teacher's } \\
\text { instructions well }\end{array}$ \\
\hline
\end{tabular}

\begin{tabular}{|c|c|c|}
\hline 2 & $\begin{array}{l}\text { Teachers have not } \\
\text { been able to create an } \\
\text { attractive learning } \\
\text { atmosphere for } \\
\text { students in distance } \\
\text { learning }\end{array}$ & $\begin{array}{l}\text { Students feel bored } \\
\text { with current learning } \\
\text { activities }\end{array}$ \\
\hline 3 & $\begin{array}{l}\text { The teacher explains } \\
\text { the material properly } \\
\text { and correctly }\end{array}$ & $\begin{array}{l}\text { Students receive the } \\
\text { material presented by } \\
\text { the teacher properly } \\
\text { and correctly, so that } \\
\text { they can apply it to } \\
\text { their daily life }\end{array}$ \\
\hline 4 & $\begin{array}{l}\text { Teachers sometimes } \\
\text { experience network } \\
\text { disruption and some } \\
\text { older teachers have } \\
\text { limitations when doing } \\
\text { distance learning }\end{array}$ & $\begin{array}{l}\text { Students sometimes } \\
\text { experience problems } \\
\text { in the network and } \\
\text { some students do not } \\
\text { have supporting } \\
\text { facilities when doing } \\
\text { distance learning }\end{array}$ \\
\hline 5 & $\begin{array}{l}\text { Some teachers feel that } \\
\text { doing learning is much } \\
\text { more difficult than } \\
\text { face-to-face learning }\end{array}$ & $\begin{array}{l}\text { Students find face-to- } \\
\text { face learning more } \\
\text { enjoyable than } \\
\text { distance learning }\end{array}$ \\
\hline 6 & $\begin{array}{l}\text { The teacher gives } \\
\text { difficult questions to } \\
\text { test students' abilities }\end{array}$ & $\begin{array}{l}\text { Students feel curious } \\
\text { if given a question } \\
\text { but do not find an } \\
\text { answer }\end{array}$ \\
\hline 7 & $\begin{array}{l}\text { The teacher delivered } \\
\text { the material in an } \\
\text { unusual way }\end{array}$ & $\begin{array}{l}\text { Students like it when } \\
\text { the teacher explains } \\
\text { unusual material }\end{array}$ \\
\hline 8 & $\begin{array}{l}\text { The teacher focuses on } \\
\text { providing material } \\
\text { when the learning } \\
\text { takes place }\end{array}$ & $\begin{array}{l}\text { Students focus on } \\
\text { paying attention to } \\
\text { the teacher while } \\
\text { learning is taking } \\
\text { place }\end{array}$ \\
\hline 9 & $\begin{array}{l}\text { The teacher delivers } \\
\text { the material briefly }\end{array}$ & $\begin{array}{l}\text { Students like the } \\
\text { delivery of the } \\
\text { teacher's material } \\
\text { briefly }\end{array}$ \\
\hline 10 & $\begin{array}{l}\text { Teachers often provide } \\
\text { homework. }\end{array}$ & $\begin{array}{l}\text { Students feel lazy if } \\
\text { the teacher gives } \\
\text { homework every day }\end{array}$ \\
\hline
\end{tabular}

\section{CONCLUSION}

Based on the discussion and research that has been conducted regarding the effect of the effectiveness of online Civics learning on student learning motivation, it can be concluded that the following:

1. The adequacy of online Civics learning is less successful for understudies of SMAN 2 Padalarang, this is because of the absence of understudies in understanding the arrangement of material clarified by the instructor during learning through online strategies, as opposed to the typical learning techniques, understudies can catch material well because of the association among educators and understudies who are not restricted by things that are in internet learning are demonstrated in the 
aftereffects of the examination that has been finished. Particularly in Civics realizing which gives understanding and information about citizenship, numerous understudies consider this exercise significant to realize that how generally will be a productive member of society as per what is given in Civics learning.

2. The current learning process makes students at SMAN 2 Padalarang have poor learning motivation due to feelings of boredom and boredom due to the unusual learning process. This is triggered by the psychological condition of students who are disturbed by internal and external factors that have been described in the previous discussion, this is what makes students' learning motivation decrease at this time.

3. The effectiveness of online Civics learning has an effect on student learning motivation at SMAN 2 Padalarang because there is a link between the online Civics learning process that is less effective for students while Civics learning is needed by students, this of course has a major effect on student learning motivation which makes student learning motivation decreased according to the results of research that has been done by researchers.

\section{REFERENCES}

[1] A. Emda, "Kedudukan Motivasi Belajar Siswa Dalam Pembelajaran," Lantanida J., no. 5, hal. 93196, 2017.
[2] P. W. James, Teknik Mengajar Sistematis. Jakarta: Rieka Cipta, 2003.

[3] D. Richard, Pembelajaran Efektif (Terjemahan). Jakarta: Grasindo, 1996.

[4] M. N. Somantri, Menggagas Pembaharuan Pendidikan IPS. Bandung: Remaja Rosdakarya dan PPs UPI, 2001.

[5] S. Ahmad, Teori Belajar dan Pembelajaran di Sekolah Dasar. Jakarta: Kencana Prenada Media Group, 2013.

[6] C. Kansil, Pendidikan Pancasila Dan Kewarganegaraan. Jakarta: Erlangga, 2004.

[7] A. . Sardiman, Interaksi dan Motivasi Belajar Mengajar. Jakarta: Raja Grafindo Persada, 2007.

[8] Slameto, Belajar dan Faktor-faktor yang mempengaruhinya. Jakarta: Rineka Cipta, 2010.

[9] W. S. Winkel, Psikologi Pengajaran. Jakarta: Gramedia, 1996.

[10] Sugiyono, Metode penelitian kuantitatif kualitatif dan R\&D. Bandung: Alfabeta, 2012.

[11] Sugiyono, Metode Penelitian Kuantitatif Kualitatif dan $R \&$ \& . Bandung: CV. Alfabeta, 2017.

[12] B. Bugin, Penelitian Kualitatif. Jakarta: Prenada Media, 2011. 